\title{
The Application of Reconciliation in Muslim Divorce Cases Caused by the Domestic Violence: An Analysis Between Islamic and Malaysian Law
}

Nadzrah Ahmad, Rahmawati Mohd Yusoff, Rohaiza Abd Rokis, Wan Mazwati Wan Yusoff, Norzulaili Mohd Ghazali, Adibah Abdul Rahim

To Link this Article: http://dx.doi.org/10.6007/IJARBSS/v11-i10/10764

DOI:10.6007/IJARBSS/v11-i10/10764

Received: 04 August 2021, Revised: 30 August 2021, Accepted: 22 September 2021

Published Online: 05 October 2021

In-Text Citation: (Ahmad et al., 2021)

To Cite this Article: Ahmad, N., Yusoff, R. M., Rokis, R. A., Yusoff, W. M. W., Ghazali, N. M., \& Rahim, A. A. (2021). The Application of Reconciliation in Muslim Divorce Cases Caused by the Domestic Violence: An Analysis Between Islamic and Malaysian Law. International Journal of Academic Research in Business and Social Sciences, 11(10), 263-273.

\section{Copyright: @ 2021 The Author(s)}

Published by Human Resource Management Academic Research Society (www.hrmars.com)

This article is published under the Creative Commons Attribution (CC BY 4.0) license. Anyone may reproduce, distribute, translate and create derivative works of this article (for both commercial and non-commercial purposes), subject to full attribution to the original publication and authors. The full terms of this license may be seen at: http://creativecommons.org/licences/by/4.0/legalcode

\section{Vol. 11, No. 10, 2021, Pg. 263 - 273}




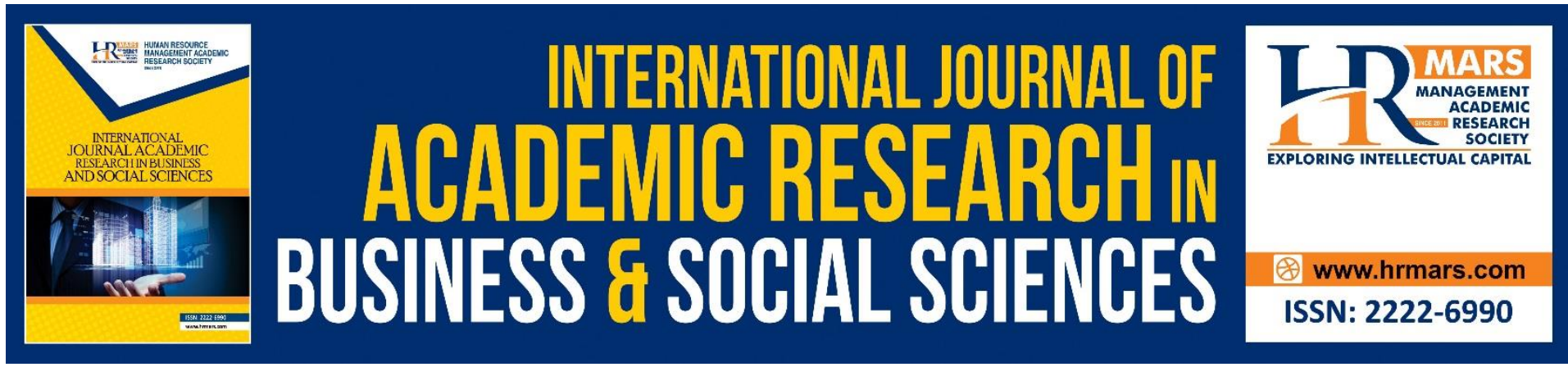

\title{
The Application of Reconciliation in Muslim Divorce Cases Caused by the Domestic Violence: An Analysis Between Islamic and Malaysian Law
}

\author{
Nadzrah Ahmad ${ }^{1}$, Rahmawati Mohd Yusoff ${ }^{2}$, Rohaiza Abd \\ Rokis $^{3}$, Wan Mazwati Wan Yusoff ${ }^{4}$, Norzulaili Mohd Ghazali ${ }^{5}$, \\ Adibah Abdul Rahim 6 \\ ${ }^{1}$ Associate Professor, Department of Qur'an and Sunnah, Kulliyyah of Islamic Revealed \\ Knowledge and Human Sciences, International Islamic University Malaysia, P.O. Box 10, \\ 50728 Kuala Lumpur, Malaysia, ${ }^{2}$ Senior Lecturer, Universiti Teknologi Mara (UiTM), \\ Cawangan Johor, Kampus Segamat, 85000 Segamat, Johor, Malaysia, ${ }^{3}$ Associate Professor, \\ Department of Sociology and Anthropology, Kulliyyah of Islamic Revealed Knowledge and \\ Human Sciences, International Islamic University Malaysia, P.O. Box 10, 50728 Kuala \\ Lumpur, Malaysia, ${ }^{4}$ Assistant Professor, Department of Fundamental and Interdisciplinary \\ Studies, Kulliyyah of Islamic Revealed Knowledge and Human Sciences, International Islamic \\ University Malaysia, P.O. Box 10, 50728 Kuala Lumpur, Malaysia, ${ }^{5}$ Senior Lecturer, Faculty of \\ Quranic and Sunnah Studies, Universiti Sains Islam Malaysia, Bandar Baru Nilai, 71800 Nilai, \\ Negeri Sembilan, Malaysia, ${ }^{6}$ Associate Professor, Kulliyyah of Islamic Revealed Knowledge \\ and Human Sciences, International Islamic University Malaysia, P.O. Box 10, 50728 Kuala \\ Lumpur, Malaysia. \\ Email: anadzrah@iium.edu.my,rahmawatimy@uitm.edu.my, \\ rohaiza@iium.edu.my,wanmazwati@iium.edu.my,norzulaili@usim.edu.my,
} adibahar@iium.edu.my

\begin{abstract}
Recently, there has been an increase in cases of domestic violence in Malaysia especially during the enforcement of the Movement Control Order (MCO) following the Covid-19 pandemic. In most cases, the marriage abused with domestic violence will usually end up with divorce. However, in Islamic law, there is a concept of reconciliation and the issue arises if the divorce is due to domestic violence, is the wife i.e the victim obliged to follow her husband if the husband wants to reconcile to them in a state of iddah? Therefore, this research seeks to identify the issue of reconciliation in divorce caused by domestic violence cases based on Islamic and Malaysian law. Hence, using qualitative methods of research, the issues are examined from the relevant literature including primary and secondary materials, governing statutes in Malaysia and from the Islamic perspective based on Qur'an, Sunnah, and views of Muslim jurists as well as contemporary Islamic scholars. The research finds that the main objective of reconciliation is to rehabilitate the relationship between husband and wife and the principle of reconciliation in Malaysian law is in line with the principle of Islamic law.
\end{abstract}


However, in the case of divorce due to a case of domestic violence, the wife can reject the reconciliation from the husband if she is worried that the said reconciliation will bring darar (harm) to her. The research also identifies the need for further research for a better platform mechanism that enable the women in knowing their right, remedies, seeks assistance and functioning as a complete information for reference for them to initiate the legal process and uphold their rights towards the domestic abuse.

Keywords: Reconciliation, Domestic Violence, Islamic Law, Malaysian Law.

\section{Introduction}

In Malaysia, the New Straits Times reported a rapid rise of domestic violence cases received by Kuala Lumpur Hospital in 2016 as compared to the previous years (Bernama, 2016). Then, it is reported the increase of domestic violence cases reported in Malaysia whereby Malaysia has seen a spike $57 \%$ increase in the number of domestic violence up to 26 March 2020 (Arumugam, 2020). According to statistics from the Royal Malaysian Police (PDRM) during January to December 2020, a total of 5,260 cases of domestic violence were investigated, while referring to Ministry of Women, Family and Community Development (MWFCD)'s Talian Kasih statistics, during the same period, a total of 2,540 cases of domestic violence were received. Apart from that, for the first four months of 2021, from January to April, a total of 902 cases of domestic violence have been reported (Ariffin, 2021).

Nevertheless, it must be noted that the local empirical studies and official records provide limited information on the number of cases, methods, risks and preventive measures of domestic violence, and it is submitted that the unreported cases are far more than the ones reported and documented in the available data (Kamruddin, 2013).

However, the issue that arises is that if the divorce is due to domestic violence, is the wife of the victim obliged to follow her husband if the husband wants to reconcile with them in a state of iddah? These issues and problems will be elaborated further in this research.

\section{Reconciliation Based on Islamic Law}

Reconciliation is from an Arabic word al-raj'ah which means the time of return (Ibn Manzur, $1414 \mathrm{H}$ ). It is said that a man returned to his place which means he coming back, in the opposite of going away (Al-Abbas, n.d). Technically, al-raj'ah means a woman's return to

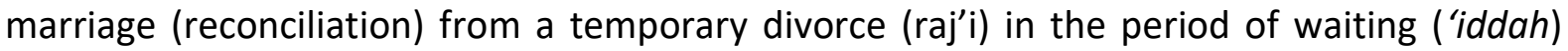
without appealing the marriage contract (Manzur, 1414H; Al-Syirbini, 1994).

The basic legal ruling with regards to a reconciliation of a marriage contract permissibility (mubah). However, it will be changed based on the situation that occurred is either obligatory (wajib) or preferable (mandub) or reprehensible (makruh) or impermissible (haram) (Al-Kasani, 1986; Al-Bahuti, n.d). There are some Quranic verses which are specified so. For example:

"And their husbands have more right to take them back in this [period] if they want reconciliation." (Al-Quran, 2: 228)

Then:

"Divorce is twice. Then, either keep [her] in an acceptable manner or release [her] with good treatment." (Al-Quran, 2: 229)

From the above verses, the husband who divorces his wife can reconcile back with his wife, providing she is still in her period of waiting. The aim is by reconcile his wife back, is 
righteous and to bring things back to normal. However, this ruling applies where the husband is eligible to take his divorced wife back in two times only. It is sinful to committing any harm or injustice against the wife. ÑAli bin Abu Talhah reported that Ibn 'Abbas said:

"When the man divorces his wife twice, let him fear Allah, regarding the third time. He should either keep her with him and treat her with kindness or let her go her way with kindness, without infringing upon any of her rights."

There are also traditions of the Prophet (PBUH) on the reconciliation issue. In a situation, the Prophet (PBUH) divorced xaflah, and then he reconciles her back in marriage (Dawud, n.d). It is also narrated by Salim that 'Abd Allah bin 'Umar told him that he had divorced his wife while she was in her menses. Thus, 'Umar informed the Prophet (PBUH) of that. The Prophet (PBUH) became very angry at that and said:

"Ibn 'Umar must return her to his house and keep her as his wife till she becomes clean and then menstruates and becomes clean again, whereupon, if he wishes to divorce her, he may do so while she is still clean and before having any sexual relations with her, for that is the legally prescribed period for divorce as Allah has ordered." (AlBukhari, no. 4908)

On another occasion, Fatimah bint Qays reported that she came to the Prophet (PBUH) and said:

"I am the daughter of 'Ali Khalid and my husband named so and so, sent word to me divorcing me. I asked his family for provision and shelter but they refused. They said, 'O Messenger of Allah, he sent word to her divorcing her thrice." Then the Prophet (PBUH) said, "The woman is still entitled to provision and shelter if the husband can still take her back." (Al-Nasai, no. 3403)

Therefore, the Muslim scholars are unanimously agreed that if a husband divorced his wife, either one or two times of divorces, he is entitled more to reconcile her back until the end of the waiting period (Al-Munzir, 2004).

\section{Conditions of the Reconciliation Husband and Wife}

The majority of the Muslim scholars which include the Maliki, the Shafie and the Hanbali schools of thought are observed that the husband who would like to reconcile must be Muslim at the time of the reconciliation (Al-Hattab, 1992; Al-Syirbini, 1994, Al-Bahuti, n.d). The husband must also reach the age of puberty (al-baligh) as according to the Maliki and the Shafie schools of thought (Al-Hattab, 1992; Al-Syirbini, 1994). In contrast, the Hanbali school of thought is viewed that the reconciliation is valid if the husband reaches the age at which a child can discern between right and wrong (al-mumayyiz) (Al-Bahuti, n.d). The husband also must be sound mind (al-Ñaql) as according to the majority of the Muslim scholar (which include the Maliki, the Shafie, the Hanbali and a view from the Hanafi schools of thought) (AlHattab, 1992; Al-Syirbini, 1994). The traditions of the Prophet (PBUH) which is being as an argument once the Prophet (PBUH) said:

"The pen has been lifted from three: From the sleeper until he wakes up, from the minor until he grows up, and from the insane until he comes back to his senses or recovers." (Al-Nasai, no 3432) 
Among the four schools of thought, only the Shafie school of thought states that the husband who wishes to reconcile the marriage must be in a voluntary manner and not being coerced (Al-Syirbini, 1994). This opinion is supported by Ibn Hazm as he states that:

"Coercion is divided into two parts which are coercion to speak and coercion to act. Coercion to speak will give non-effect impacts such as infidelity (al-kufr), slander (alqazf), confession (al-iqrar), marriage (al-nikah), marriage other people (al-inkah) either a guardian of a bride (al-wali) or representative of a guardian (wakil al-wali), reconciliation (al-raj'ah), and divorce (al-talaq)."

The Prophet (PBUH) said to the effect:

"Allah has forgiven my nation for mistakes and forgetfulness, and what they are coerced to do." (Majah, n.d)

The same conditions above must be fulfilled by the wife who would like to reconcile. She must be Muslim at the time of the reconciliation since the purpose of reconciliation has legalized the marriage so that the apostasy is against the purpose (Al-Syirbini, 1994). This is the view by the majority of the Muslim scholars which include the Maliki, the Shafie and the Hanbali schools of thought (Al-Wahhab, 1999; Al-Nawawi, 2005; Al-Bahuti, n.d). Next, the

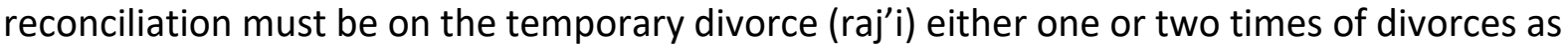
Allah the Almighty said in the Holy Quran:

"Divorce is twice. Then, either keep [her] in an acceptable manner or release [her] with good treatment." (Al-Quran, 2: 229)

Imam al-Shafie commented that the above verse is specified to temporary divorce (raj'i) either one or two only (Al-Shafie, 1990). Similar guidance has shown in the tradition of the Prophet (PBUH) as al-xasan reported that the sister of Ma'qil bin Yasar was married to a man and then that man divorced her and remained away from her till her waiting period ('iddah) expired. Then the man demanded her hand in marriage, but Ma'qil got angry out of pride, haughtiness, disagreed her to remarry him and said, "He kept away from her when he could still retain her, and now he demands her hand again?" Then Allah revealed:

"And when you divorce women and they have fulfilled their term, do not prevent them from remarrying their [former] husbands if they agree among themselves on an acceptable basis. That is instructed to whoever of you believes in Allah and the Last Day. That is better for you and purer, and Allah knows and you know not." (Al-Quran, 2: 232)

Therefore, the Prophet (PBUH) directed and recited the verse for Ma'qil. Consequently, Ma'qil gave up his pride and haughtiness and yielded to Allah's order (AlBukhari, no. 5331). Therefore, Muslim scholars are unanimously agreed that the

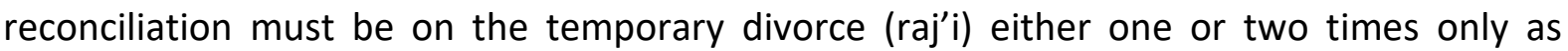
mention by Ibn al-Munzir (Al-Munzir, 2004). Then, the reconciliation be must with the wife who has had her sexual intercourse (al-dukhul). Thus, a wife who has not yet has had her sexual intercourse with her husband will have no waiting period after her divorce. The husband and wife have not right to reconcile to their marriage. Allah the Almighty said to the effect: 
"O You who have believed, when you marry believing women and then divorce them before you have touched them, then there is not for you any waiting period to count concerning them. To provide for them and give them a gracious release." (Al-Quran, 33: 49)

The above verse indicates that a wife who has been divorced by her husband would have no waiting period if she not yet had her sexual intercourse with her husband. The husband has no right to reconcile with her divorced wife and him also no financial obligation toward his former wife after the divorce. Muslim scholars are unanimously agreed on the matter as mention by Ibn al-Munzir (Al-Munzir, 2004). Next, the reconciliation must be during the waiting period of the wife (al-'iddah). If the period lapse, they have no right to reconcile as Allah the Almighty said:

"And their husbands have more right to take them back in this if they want reconciliation." (Al-Quran, 2: 228)

The husband has more right to reconcile his wife back in this, which means in this waiting period as mention by Ibn Munzir and being the consensus of all Muslim scholars (AlMunzir, 2004). Otherwise, a man should adhere to a new marriage contract (al-'aqd) if he wishes for his former wife. Also, the reconciliation must be with a wife who does not pay some of the amount of ransom (al-fidya) to her husband. By paying that amount, she intended to release herself from her husband and her husband will no longer have the right to reconcile with her (Al-Bahuti, n.d). Muslim scholars are consensus on this matter as mention by Ibn alRif'ah al-Ansari (Al-Ansari, 2009). Allah the Almighty said in the Holy QurÉn:

"But if you fear that they will not keep [within] the limits of Allah, then there is no blame upon either of them concerning that by which she ransoms herself." (Al-Quran, 2: 229)

Finally, according to al-Shafie, a husband who wishes to reconcile must be specified which one of his wife he wishes to, in the situation when he divorces a wife but ambiguously which wife and he divorces all his wife and wishes to reconcile to a wife (Al-Syirbini, 1994).

The above requirements either for the husband or for the wife are intended to make the reconciliation fulfil its objective which is for the betterment relationships between spouses. It is the wisdom of the urgency of reconciliation as a man may divorce his wife and then regret his action (Al-Kasani, 1986). Allah the Almighty said:

"You know not; perhaps Allah will bring about after that a [different] matter." (AlQuran, 65: 1)

For that reason, the mistake which leads to an act of divorce needs to be corrected. If there is no reconciliation, the mistake will not be able to be corrected. Thus, it is the great wisdom from Allah the Almighty.

\section{Requirement of Wife's Consent to Reconcile}

The rule is the wife's consent is not required for the reconciliation. Thus, the husband has to reconcile to his wife, whether she consented or not. A husband has more right compared to his wife in this matter as Allah the Almighty said:

"And their husbands have more right to take them back in this if they want reconciliation." (Al-Quran, 2: 228) 
Ibn Munzir mentions that this rule has become a consensus of the Muslim scholar (AlMunzir, 2004). The same consensus recited by Ibn Hazm, 'Ala' al-Din al-Samarqandi, Ibn Rushd, Ibn Qudamah, al-Qurtubi, al-'Ayni, Ibn al-Hamam, al-San'ani and others (Al-Qahtani, 2012). However, it is reprehensible (makruh) to reconcile a marriage contract if it is expected to harm and illegal (haram) if it harms purpose (Al-Kasani, 1986; Al-Bahuti, n.d). Allah the Almighty said to the effect:

"And when you divorce women and they have [nearly] fulfilled their term, either retain them according to acceptable terms or release them according to acceptable terms, and do not keep them, intending harm, to transgress [against them]. And whoever does that has certainly wronged himself. And do not take the verses of Allah in jest." (Al-Quran, 2: 231)

This is an order from Allah to men that if one of them divorces his wife with a reversible divorce, he should treat her kindly. But, whenever her time of waiting comes to an end, he either takes her back in a different way, like seeing that he has taken her back, and he lives with compassion. Or, he should release her after her waiting period finishes and then kindly asks her to depart from his house, without disputing, fighting with her or using foul words. Besides, it is impossible to reconcile except for those who want to improve their selves and relationships and intend the goodwill (Taymiyah, 1418H). As the reconciliation is for the objective of the betterment relationships between spouses, any harm purpose will depart from the objective.

\section{Domestic Violence from Islamic and Malaysian Law}

Domestic violence or abusive behaviour directed by one family or household member against another (Merriam-webster.com, n.d). In order to curb this issue, the Domestic Violence Act 1994 was passed in Malaysia in 1994 with aim to help victims in domestic violence cases (Columbini et al., 2011).

By virtue of Section 2 of Domestic Violence Act 1994, "domestic violence means the commission of any of the following acts":

(a) "wilfully or knowingly placing, or attempting to place, the victim in fear of physical injury;"

(b) "causing physical injury to the victim by such act which is known or ought to have been known would result in physical injury;"

(c) "compelling the victim by force or threat to engage in any conduct or act, sexual or otherwise, from which the victim has a right to abstain;"

(d) "confining or detaining the victim against the victim's will; or"

(e) "causing mischief or destruction or damage to property with intent to cause or knowing that it is likely to cause distress or annoyance to the victim, by a person against-“

(i) "his or her spouse;"

(ii) "his or her former spouse;"

(iii) "a child;"

(iv) "an incapacitated adult; or"

(v) "any other member of the family."

There are certain forms of domestic violence among others physical abuse, emotional abuse, and financial abuse. According to the AMEND Workbook for Ending Violent Behavior, any physically hostile behaviour, withholding of bodily needs, indirect physically hurtful 
action, or the fear of physical abuse is considered physical abuse. Meanwhile, any activity that exploits another's vulnerability, insecurity, or character is considered emotional abuse. Apart from that, financial abuse is a method of gaining control over a victim by manipulating their financial resources. This can include, but is not limited to, controlling the family's income and either denying or severely restricting the victim's access to family cash. This could involve concealing financial secrets or hidden accounts, putting the victim on an allowance or giving them no control over how their money is spent, or forcing them to hand over their wages to the offender. The victim may potentially lose their job or be prevented from getting a job as a result of the assault. By making the victim late for work, refusing to give transportation to work, or calling/harassing them at work, the abuser might cause the victim to lose their job. (Lindsey et al., 1993).

Apart from that, Section 3 of Domestic Violence Act 1994 provides that the provisions of this Act shall be read together with the provisions of the Penal Code which concluded that the domestic violence is categorised as a criminal case. By virtue of Section $18 \mathrm{~A}$ from the Domestic Violence Act 1994 (Amendment 2012) (ActA1414) states that these offenses involving domestic violence are deemed to be arrestable offenses.

The Domestic Violence Act 1994 offers battered women protection from the abuser in the form of protective orders such as Emergency Protection Order (EPO), Interim Protection Order (IPO), Protection Order (PO), and provides for compensation and counselling to be made available to them (Dusuki, 2017). Besides, there are other forms of remedies such as rehabilitation programmes provided for the victims.

In Islamic law, domestic violence was condemned by the Prophet (PBUH) in both deed and word. The Prophet (PBUH) said, "Never beat God's handmaidens (female believers)." (Asad, M., 1980) The Prophet (PBUH) also said, "Could any of you beat his wife as he would beat a slave, and then lie with her in the evening?" (Al-Bukhari, 1422H). The Prophet (PBUH) had a reputation for never striking a woman or a children. Aisha is reported to have said, "The Prophet never beat any of his wives or servants; in fact, he did not strike anything with his hand except if he were to struggle in the cause of God." (Al-Asqalani, 1987)

In reconciliation, a husband should not intend to afflict harm to his wife it, rather he should intend to rehabilitate their relationship as Allah the Almighty said:

"And their husbands have more right to take them back in this [period] if they want reconciliation. And due to the wives is like what is expected of them, according to what is reasonable." (Al-Quran, 2: 228-229)

The verse indicates that the wife has certain rights on her husband, just as he has certain rights on her, and each is obliged to give the other spouse his due rights. The Prophet (PBUH) said:

"Fear Allah regarding your women, for you have taken them by Allah's covenant and were allowed to enjoy with them sexually by Allah's Words." "You have the right on them that they do not allow anyone you dislike sitting on your mat. If they do that, then discipline them leniently. They have the right to be spent on and to be bought clothes in what is reasonable." (Muslim, no. 1218)

Thus, it is reprehensible (makruh) to reconcile a marriage contract if it is expected to harm and illegal if it harms purpose (Al-Kasani, 1986; Al-Bahuti, n.d). A wife must prove to the court that her husband will be afflicted he with harm if they reconciled (Islamtoday.net, n.d). 
It is sinful for those husbands who divorces his wife and then reconcile with her back, and he intends to afflict harm.

Apart from than that, a wife is permissible to ask for a divorce if harm is afflicted upon her. Some examples are the husband's incapability to fulfil the wife's rights, such as maintenance, cohabitation, housing, etc. The wife has the choice between being patient or request for a divorce. A wife also permissible to ask for a divorce is the husband abusive his wife, beating and cursing for no legitimate reason even if it happens once and not repeated (Al-Misri, 2005). For example, is the husband called his wife, "Oh dog's daughter!" or "Oh infidel's daughter!" and other (Al-Dusuqi, n.d). Therefore, if a wife is permissible to ask for divorce due to harm which is afflicted to her during marriage time, it is also permissible to a wife to refuse to the reconciliation during waiting period on the reason of harm is expected in the reconciliation.

The principle of reconciliation in Malaysian law is in line with the principle of Islamic law which can be seen through the Section of 51 of Islamic Family Law (Federal Territory) Act 1984 (IFLA). By virtue of Section 51(1), "revocable divorce" "means a divorce by one or two talaq not followed by completion of 'iddah, and "recohabit" means resume conjugal relations within the period before the divorce has become irrevocable."

"If, after a revocable divorce, recohabitation takes place by mutual consent, the parties shall within seven days report the fact of recohabitation and other relevant particulars to the Registrar for the kariah masjid in which they reside" (Section 51(2), IFLA 1984).

"If after a revocable divorce the husband pronounces a ruju' (reconcile) and the wife has consented to the ruju', she may, on the application of the husband, be ordered by the Court to resume conjugal relations, unless she shows good cause to the contrary, according to Hukum Syara', in which case the Court shall appoint a conciliatory committee as provided under Section 47 and that section shall apply accordingly" (Section 51(8), IFLA 1984).

It is also permissible to a wife to refuse to the reconciliation during waiting period on the reason of harm is expected in the reconciliation as Section 51(9) of IFLA 1984 provides that "if after a revocable divorce the husband pronounces a ruju' but the wife has not consented to the ruju' for reasons allowed by Hukum Syara', she shall not be ordered by the Court to resume conjugal relations, but the Court shall appoint a conciliatory committee as provided under Section 47 and that section shall apply accordingly."

\section{Conclusion}

Therefore, it can be concluded that the objective of reconciliation from divorce is to rehabilitate the relationship between husband and wife. However, if it is feared that there will be darar (harm) from the reconciliation, then the wife can reject the reconciliation. This is because if a wife can ask for a divorce if there is darar (harm) in their marriage, thus, if the divorce is due to the case of domestic violence, then the wife also can reject the reconciliation on the grounds of darar (harm) will occur as a result of the reconciliation. The research submitted that the husband must protect the rights of the wife by treating them with love and not vise versa by hurting the wife. If the husbands can immerse themselves in the rights of these wives as outlined in the Quran and Sunnah, then the cases of domestic violence will not occur. As a result, the children and wife will be able to live happily in a peaceful, calm, and harmonious family. The research also identifies the need for further research for a better platform mechanism that enable the women in knowing their right, remedies, seeks assistance and functioning as a complete information for reference for them to initiate the legal process and uphold their rights towards the domestic abuse. 


\section{Contribution}

This study originates a new findings for the issue of reconciliation in divorce caused by domestic violence cases. It is submitted that in the case of divorce due to a case of domestic violence, the wife can reject the reconciliation from the husband if she is worried that the said reconciliation will bring darar (harm) to her.

\section{Acknowledgment}

The authors fully acknowledge the sponsorship from the Malaysian Ministry of Higher Education Fundamental Research Grant Scheme (FRGS19-192-0801) entitled A Framework of Women Empowerment and Inclusive Development to Enhance Economic Involvement and Social Rights Towards Preventing Domestic Violence for the completion of this research project.

\section{References}

Abidin, M. A. (1992). Rad Al-Mukhtar ala Al-Dur Al-Mukhtar. Beirut: Dar Al-Fikr.

Al-Abbas, A. (n.d). Al-Misbah al-Munir fi Gharib al-Sharí al-Kabir. Beirut: Al-Maktbah alIlmiyah.

Al-Ansari, A. A. N A. (2009). Kifayah al-Nabih fi Syarh al-Tanbih. N.p.: Dar al-Kutub al-Ilmiyah. Al-Asqalani, A. (1987). Fath al-Bari Bi Syarah Sahih al-Bukhari. Dar al-Riyan.

Al-Bahuti, M. (n.d). Kashaf al-Qina' an Matan al-Iqna'. N.p.: Dar al-Kutub al-Ilmiyah.

Al-Bahuti, M. (n.d). Sharh Muntaha al-Iradat. N.p.: Dar al-Kutub al-Ilmiyah.

Al-Bukhari, A. A. M. (1422H). Sahih Al-Bukhari. N.p.: Dar Tuq Al-Najah.

Al-Dusuqi, M. (n.d). Hashiyah al-Dusuqi ala al-Sharh al-Kabir. N.p.: Dar al-Fikr.

Al-Fatawa. (2003). Islamtoday.net. 2003, May, 19.

http://www.islamtoday.net/fatawa/quesshow-60-17917.htm

Al-Hattab, S. A. A. (1992). Mawahib al-Jalil Sharh Mukhtasar Khalil. N.p.: Dar al-Fikr.

Al-Kasani, A. A. B. (1986). Badai' Al-Sanai' fi Tartib Al-Sharai'. Dar Al-Kutub Al-Ilmiyyah.

Al-Misri, D. (2005). Muktasar al-Allamah Khalil. Al-Qaherah: Dar al-Hadith.

Al-Munzir, A. B. M. (2004). Al-Ishraf 'ala Mazahib Al-Ulama'. UAE: Maktabah Makah alThaqifiyah.

Al-Nasai, A. (1986). Al-Sunan al-Sughra. Halab: Maktab al-Matbu'at al-Islamiyah.

Al-Nawawi, A. Z. M. Y. (2005). Minhaj al-Talibin wa Umdah al-Muftin fi al-Fiqh. N.p.: Dar alFikr.

Al-Quran Karim.

Al-Shafie, A. A. M. (1990). Al-Umm. Beirut: Dar Al- Ma'rifah.

Al-Syirbini, S. M. (1994). Mughni Al-Muhtaj ila Ma'rifah Maani Alfaz Al-Minhaj. Dar al-Kutub al-Ilmiyyah.

Al-Wahhab, A. A. M. A. (1999). Al-Ishraf 'ala Nukat Masail al-Khilaf. N.p.: Dar Ibn Hazm.

Arifin, L. (2021). "Kes Keganasan Rumah Tangga Meningkat Sepanjang PKP." Berita Harian Online, May 4, 2021.

https://www.bharian.com.my/berita/nasional/2021/05/813664/kes-keganasanrumah-tangga-meningkat-sepanjang-pkp

Arumugam, T. (2020). "MCO-linked Domestic Violence Rises." New Straits Times, April 4, 2020. https://www.nst.com.my/news/exclusive/2020/04/581233 /mco-linkeddomestic-violence-rises.

Asad, M. (1980). The Message of the Qur'an. Gibraltar: Dar al-Andalus. 
Bernama. (2016). "Domestic Violence Cases on the Rise." The Star, July 9, 2016. https://www.thestar.com.my/news/nation/2016/07/09/hkl-rise-in-domesticviolence-cases/

Dawud, A. (n.d). Sunan Abi Dawud. Beirut: Maktabah al-Asriyah. Domestic Violence Act 1994. Domestic Violence. (n.d). Merriam-Webster.com Dictionary, Merriam-Webster. https://www.merriam-webster.com/dictionary/domestic\%20violence.

Dusuki, F. N. (2017). "A Legal Oveview on the Protection of Women Against Violence in Malaysia." In Abdul Monir Yaacob \& Nurul'uyum Haji Zainal (Eds.). Women and Development in the 21 $1^{\text {st }}$ Century: The Way Forward. Selangor: Universiti Islam Malaysia.

Columbini, M., Ali, S. H., Watts, C., \& Mayhew, S. H. (2011). "One Stop Crisis Centres: A Policy Analysis of the Malaysian Response to Intimate Partner Violence." Health Research Policy and Systems, 9: 25, 3-4.

Habib, S. A. (1988). Al-Qamus al-Fiqhi Lughah wa Istilah. Dimashq: Dar al-Fikr.

Hazm, A. M. A. (n.d). Al-Muhalla. Beirut: Dar al-Fikr.

Islamic Family Law (Federal Territory) Act 1984.

Kamaruddin, Z., Oseni, U. A. (2012). "Between Ideals and Reality: Violence against Women And the Real Image of Women in Islam." The Institute of Oriental Philosophy.

Kathir, A. F. I. (1999). Tafsir Al-Qur'an al-Azim. N.p: Dar Toybah li Al-Nashr wa Al-Tawzi'.

Lindsey, M., McBride, R. W., Platt, C. M. (1993). Amend: Workbook for Ending Violent Behavior. Gylantic Pub Co.

Majah, M. (n.d). Sunan Ibn Majah. Beirut: Dar Ihya' al-Kutub al-Arabiyah.

Manzur, M. (1414H). Lisan al-Arab. Beirut: Dar Sadir.

Muslim, A. H. A. M. (n.d). Sahih Muslim. Beirut: Dar Ihya' Al-Turath.

Qudamah, A. M. M. D. A. M. (1968). Al-Mughni. N.p.: Maktabah Al-Qahirah.

Qudamah, A. M. M. D. A. M. (1995). Al-Sharh al-Kair. Al-Qaherah: Hijr lil Taba'ah wa al-Nashr wa al-Tawzi' wa al-I'lan.

Taymiyah, T. (1418H). Al-Mustadrak ala Majmu' Fatawa Shaykh al-Islam. N.p.: Maktabah alShamilah. 